\title{
Milliliter per Hour per Milligram per Meter Squared per Day
}

National Cancer Institute

\section{Source}

National Cancer Institute. Milliliter per Hour per Milligram per Meter Squared per Day.

NCI Thesaurus. Code C120781.

A unit of concentration equal to milliliter per hour divided by milligram per meter squared per day. 